\begin{tabular}{cc|c}
\hline Tar. Bil. Der. & Tarm Bilimleri Dergisi & Journal of Agricultural Sciences \\
& $\begin{array}{c}\text { Dergi web sayfası: } \\
\text { www.agri.ankara.edu.tr/dergi }\end{array}$ & Journal homepage: \\
& www.agri.ankara.edu.tr/journal
\end{tabular}

\title{
The Effects of Different Growing Media on Growth, Flowering and Quality of Petunia grandiflora
}

\author{
Mohammad Moneruzzaman KHANDAKER ${ }^{\text {a }}$, Suraya RAHMAT ${ }^{\text {a }}$, Nadiawati ALIAS ${ }^{\text {a }}$, Khamsah Suryati \\ MOHD $^{\text {a }}$, Nashriyah MAT ${ }^{\mathrm{a}}$ \\ ${ }^{a}$ School of Agriculture Science \& Biotechnology, Faculty of Bioresources and Food Industry, Universiti Sultan Zainal Abidin, Besut \\ Campus, 22200 Besut, Terengganu, MALAYSIA
}

\section{ARTICLE INFO}

Research Article

DOI: $10.15832 /$ ankutbd.407900

Corresponding Author: Mohammad Moneruzzaman KHANDAKER, E-mail: moneruzzaman@unisza.edu.my, Tel: +6 (09) 6993450

Received: 20 March 2018, Received in Revised Form: 21 September 2018, Accepted: 04 October 2018

\begin{abstract}
A study was carried out to investigate the effects of growing media on physiology, flowering behaviour and longevity of potted petunia plants (Petunia grandiflora Juss.) under green house condition. A total of 30 potted petunia plants were used in this experiment and five different growing media namely top soil (control), vermicompost, biochar, cocopeat and peatmoss were tested. Leaf area, lateral branching, stomatal conductance and net photosynthetic rate significantly increased when the plant was grown in peatmoss and cocopeat. The highest length of lateral branch was recorded in the control treatment. In addition, peatmoss and cocopeat medium increased the number of flower, flower diameter, weight of individual flower and petal thickness significantly. Furthermore, chlorophyll $a \& b$ contents in leaves, carotenoids and anthocyanin content in flowers were also increased significantly with peatmoss and cocopeat applications. Ethylene production was reduced significantly and flower longevity of potted petunia plants increased in different growing media. There was a positive correlation between petal thickness and flower senescence, and between anthocyanin content with flower senescence in potted petunia plants. It can be concluded that peatmoss and cocopeat growing media improved the growth, quality and longevity of potted petunia flowers under green house condition.

Keywords: Growth; Development; Flower; Floriculture; Medium; Quality
\end{abstract}

(C) Ankara Üniversitesi Ziraat Fakültesi

\section{Introduction}

Petunia plants are characterized by a short life cycle, color diversity, compact plant size, and relatively easy growth. Petunias are perennials in warm climates and used in building decoration, private garden and landscape, pharmaceutical and cosmetic industries, and phytoremediation. It has been reported that flowering capacity of petunia plants can be influenced by breeding and cultivation technologies (Nishijima et al 2006). Growth regulators and substrates influence the plant growth, flowering potential and longevity of potted flowering plant (Khandaker et al 2010). Nowadays, a very important aspect in the production of potted flowering plants is the controlled and induced vegetative and floral growth by horticultural practices. 
Growth medium are known to have been effective in value adding of potted ornamental plant, and should have a best characteristics such as proper aeration, water holding capacity and adequate nutrient supply (Khobragade et al 1997). Besides that, growth medium plays an important role in physiological parameters such as plant height, number of leaves, number and diameter of florets per spike, and yield. It has been reported that the optimum amount of nutrient and environmental factors affect the plant growth, development and flowering of petunia (Zhanga et al 2012)

Petunia seedlings are commonly produced in the greenhouse in mixtures of commercial soilless bedding plant growth media, and sometimes the growth and flower production of petunia plants is low due to unsuitable growing media. In this study, several types of growing media were used as growing components of petunia to select the best adequate growing medium for managing ornamental potted plants. Currently, there is little information available on the effect of growing media on growth, flowering and longevity of petunia flowers. Besides that, the petunia flower has short longevity and floral longevity has received very little attention from ornamental plant breeders. Moreover, no information is available in the literature about the longevity of the petunia flowers. The findings of this study will help to increase floral longevity of petunia as well as other potted flowering plants which will create a significant value to further develop the floriculture industry. It is proposed that different growing media can enhance the growth, development and quality of petunia flowers under green house condition.

\section{Materials and Methods}

\subsection{Plant materials and treatment setting}

The study was conducted at the greenhouse and laboratories of the Faculty of Bioresources and Food Industry, University Sultan Zainal Abidin, Besut Campus, 22200 Besut, Terengganu, Malaysia from June 2015 to May 2016. The plant material used in this experiment was Petunia grandiflora cultivar pink. All the collected petunia seedlings are produced from sexual reproduction. The seedlings of the cultivar approximately $15 \mathrm{~cm}$ height were selected from the Beauty Garden, a commercial nursery located at Sungai Buloh, Selangor, Malaysia. Five different growing media; cocopeat $(\mathrm{pH}=4)$, biochar $(\mathrm{pH}>9)$, vermicompost $(\mathrm{pH}=$ $6.8)$, peatmoss $(\mathrm{pH}=4.5)$, and clay loam top soils $(\mathrm{pH}=6.5)$ as control were used. The seedlings were transferred in to $8 \mathrm{~cm}$ diameter and $12 \mathrm{~cm}$ height size polybags that contain different growing media. After transplanting in the growing media, pinching back of terminal bud of all the seedlings were carried out to encourage branching to produce a bushy growth. The growing temperature in the greenhouse was $24 \pm 2{ }^{\circ} \mathrm{C}$ with maximum PAR of $500-1000$ $\mu \mathrm{Em}^{-2} \mathrm{~s}^{-1}$ and relative humidity of $60 \%$ to $90 \%$. A thoroughly watering regime by a handheld sprayer was applied every day. Thirteen gram (13 g) NPK fertilizers (13:13:21) (Baja Yara mila) per polybag were applied once in every two week interval. Two months after transplanting all the petunia seedlings started flowering.

\subsection{Preparation of media and transplanting}

The growing media was placed into $8 \mathrm{~cm}$-diameter x $12 \mathrm{~cm}$-height polybags, and proper care was taken for uniform filling of all pots by soft tapping to maintain equal compaction levels. The seedlings of petunia with uniform size and age was transplanted (one seedling per polybag) when they have approximately ten (10) leaves each.

\subsection{Measurements of physiological and flowering parameters}

A young fully expanded leaf from each petunia plant was selected and leaf area was measured by using the Leaf Area Meter (CI-202, CID Bioscience, USA). The average value was recorded and leaf area was expressed in $\mathrm{cm}^{2}$. The number of bud, number of flowers, length of lateral branch, number of lateral branch, weight of individual flowers, petal thickness and flower longevity, were determined after one (1) month of transplanting of the seedling into polybags. Five flowers from the five potted 
petunia plants per treatment were selected for the measurement of petal thickness. Petal thickness of petunia flowers was measured using a Mitutoyo Vernier Scale. Five buds per pot were selected for blooming and longevity measurements. At blooming phase of petunia, eighteen leaves from six plants per treatment were selected for the measurement of plant physiological characteristics. All the measurements were taken from the center of the three (3) youngest fully expanded leaves of each plant. Relative leaf chlorophyll content was measured by using a handheld Chlorophyll Meter (SPAD-502; Minolta Japan). Three data for leaf chlorophyll content and stomatal conductance were recorded per plant and the average was calculated. Stomatal conductance of a leaf was measured by using a portable Porometer (Leaf Porometer, Model SC-1, USA). Photosynthetical characteristics of potted petunia plants were recorded from 11 am to $2 \mathrm{pm}$ every two weeks. Net photosynthetic rate of potted petunia plants was determined, in terms of $\mu$ mol $\mathrm{CO}_{2}$ fixation $\mathrm{m}^{-2} \mathrm{~s}^{-1}$, to measure the activity level of the photosynthetic Carbon metabolism. Data for net photosynthetic rate was measured using a handheld Photosynthesis System (C1-340; CID Bio-Science, USA). Three replications of readings were recorded per plant from each treatment and the data was recorded once during the experimental period.

\subsection{Determination of pigments content and ethylene production}

The chlorophyll (chl. $a \&$ chl. $b$ ) contents of the control and treated petunia leaves were determined according to the methods described in Khandaker et al (2013). Carotene content was measured by using Spectrophotometer (Genesys 20, Thermo Scientific, USA). All the pigments contents were determined at the full blooming stage of petunia flower ( 5 days after petal opening). The concentration of carotenoids was measured by using a formula of Arnon (1949). The formula to calculate the pigments concentration is as shown below:

Carotenoid $\left(\mu \mathrm{g} \mathrm{g}^{-1}\right)=[\mathrm{A} 480+(0.114 \times \mathrm{A} 663)-(0.638 \times$ A645)]/112.5
The total anthocyanin content of the hydrophilic extracts of petunia petals were measured by the $\mathrm{pH}$-differential method using cyanidin-3-glucoside as a standard, as described by Rodriguez-Saona et al (1999). At $5^{\text {th }}$ days of flower opening, petal carotenoid and anthocyanin contents were determined once during the study period. Flower ethylene production of potted petunia plants were carried out according to the method described in Khandaker et al (2013). Six flowers from six plants for each treatment were collected once at fully bloom stage and air samples were analyzed for ethylene using a Shimadzu GC-14A Gas Chromatograph. The ethylene production rates were calculated and expressed as nL flower ${ }^{-1} \mathrm{~h}^{-1}$.

\subsection{Statistical analysis}

A Completely Randomized Design (CRD) with six replications was used for the treatments in the experiment. Statistical analysis was performed by using SPSS 20 software (SPPS Inc). All data were analyzed according to one way repeated ANOVA. The means were separated using Fisher's protected least significant difference procedure when the $\mathrm{F}$ test indicated significance at $\mathrm{P} \leq 0.05$.

\section{Results}

\subsection{Leaf area, number and length of lateral branch}

Our results showed that, leaf area significantly affected by growing media (Table 1). The highest leaf area was recorded in peatmoss treatment, followed by cocopeat and vermicompost treatment. While, the smallest leaf was found in control treatment (Figure 1). The number and length of lateral branch differed significantly among treatments (Table 1). The highest value (6.4) was observed in cocopeat treatment followed by BioChar (6.0), while the lowest value (5.4) was obtained with vermicompost treatment. The highest length of lateral branch was obtained with control treatment $(49 \mathrm{~cm})$ followed by cocopeat ( 46 $\mathrm{cm})$. The lowest length was recorded in peatmoss treatment at $27.86 \mathrm{~cm}$. 
Table 1- Effects of different growing media on growth and physiological characteristics of potted Petunia grandiflora plants

\begin{tabular}{llllll}
\hline Treatment & $\begin{array}{l}\text { Leaf area } \\
\left(\mathrm{cm}^{2}\right)\end{array}$ & $\begin{array}{l}\text { No of lateral } \\
\text { branch }\end{array}$ & $\begin{array}{l}\text { Length of } \\
\text { branch }(\mathrm{cm})\end{array}$ & $\begin{array}{l}\text { Stomatal cond } \\
\left(\mathrm{mol} \mathrm{m}^{-2} \mathrm{~s}^{-1}\right)\end{array}$ & $\begin{array}{l}\text { Photosynthesis } \\
\left(\mu \mathrm{mol} \mathrm{CO}^{2} \mathrm{~m}^{-2} \mathrm{~s}^{-1}\right)\end{array}$ \\
\hline Control & $1.40 \pm 0.20 \mathrm{c}$ & $5.80 \pm 0.90 \mathrm{~b}$ & $49.00 \pm 0.80 \mathrm{a}$ & $0.35 \pm 0.20 \mathrm{c}$ & $6.00 \pm 0.42 \mathrm{c}$ \\
Vermicompost & $1.50 \pm 0.20 \mathrm{c}$ & $5.40 \pm 0.24 \mathrm{c}$ & $35.00 \pm 0.60 \mathrm{c}$ & $0.48 \pm 0.20 \mathrm{~b}$ & $7.80 \pm 0.72 \mathrm{a}$ \\
Biochar & $1.40 \pm 0.20 \mathrm{c}$ & $6.00 \pm 0.30 \mathrm{a}$ & $39.00 \pm 0.50 \mathrm{c}$ & $0.40 \pm 0.20 \mathrm{~b}$ & $6.50 \pm 0.42 \mathrm{~b}$ \\
Cocopeat & $1.60 \pm 0.20 \mathrm{~b}$ & $6.40 \pm 0.20 \mathrm{a}$ & $46.00 \pm 0.30 \mathrm{~b}$ & $0.61 \pm 0.20 \mathrm{a}$ & $8.00 \pm 0.91 \mathrm{a}$ \\
Peatmoss & $1.80 \pm 0.20 \mathrm{a}$ & $5.80 \pm 0.30 \mathrm{~b}$ & $28.00 \pm 1.20 \mathrm{~d}$ & $0.72 \pm 0.20 \mathrm{a}$ & $8.50 \pm 0.72 \mathrm{a}$ \\
\hline
\end{tabular}

Data was present in means ( \pm SE). Different means in same column followed by same letter are not different according to LSD test at $\mathrm{P}=0.05$ of probability
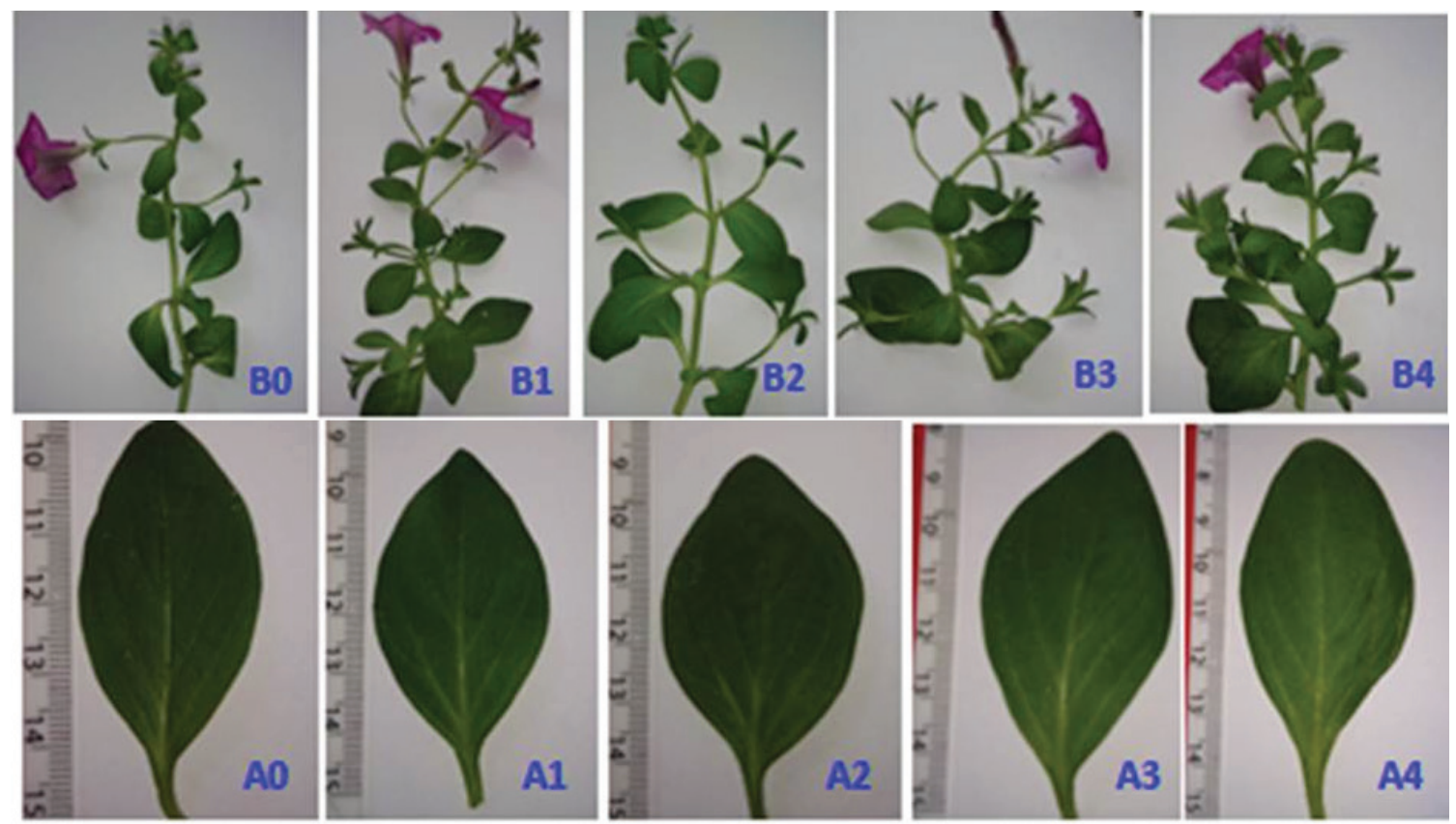

Figure 1- The effect of different growing media on number of flower bud (B) and leaf area (A) of potted petunia plants. 0, Control; 1, Vermicompost; 2, Biochar; 3, Cocopeat and 4, Peatmoss

\subsection{Stomatal conductance and photosynthetic rate}

Different growing media significantly affect the leaf stomatal activity of potted petunia plants. Stomatal conductance was the highest in peatmoss, followed by cocopeat and vermicompost treatment with a value of $0.72,0.61$ and $0.48 \mathrm{~mol} \mathrm{~m}^{-2} \mathrm{~s}^{-1}$, respectively. While, the lowest stomatal conductance was recorded in the control plant at $0.35 \mathrm{~mol} \mathrm{~m}^{-2} \mathrm{~s}^{-1}$ (Table 1). In this study, different growing media produced significant effect on photosynthesis of petunia plants. The results showed that net photosynthetic rate of petunia plant was the highest in peatmoss treatment, followed by cocopeat and vermicompost treatment, whereas, the control plant showed the lowest photosynthetic rate (Table 1). 


\subsection{Number of flower bud and flower}

The number of buds produced were significantly different among treatments at $\mathrm{P} \leq 0.05$ (Table 2). As can be seen from Figure 1, the highest bud production was obtained with BioChar (21.8) followed by peatmoss (20.13) while, the lowest number of bud was recorded in control (3.2). The maximum flower production highlights their adaptability to suitable environment. Based on the results of Figure 2 and Table 2, the mean number of flowers were significantly different between the treatments and control at $\mathrm{P} \leq 0.05$. The number of flowers per plant was the highest with cocopeat treatment (32) followed by peatmoss (29) while, the lowest number of flower was obtained in vermicompost with the mean value of 21 .

\subsection{Diameter of flower, weight of individual flower and petal thickness}

Based on Table 2 and Figure 2, the results showed that diameter of flower differed significantly among the growing media. The peatmoss treatment had the highest value $(52 \mathrm{~mm})$ followed by vermicompost $(47 \mathrm{~mm})$ whereas, the lowest flower diameter was recorded with BioChar treatment $(41 \mathrm{~mm})$. The different growing media thus produced significant
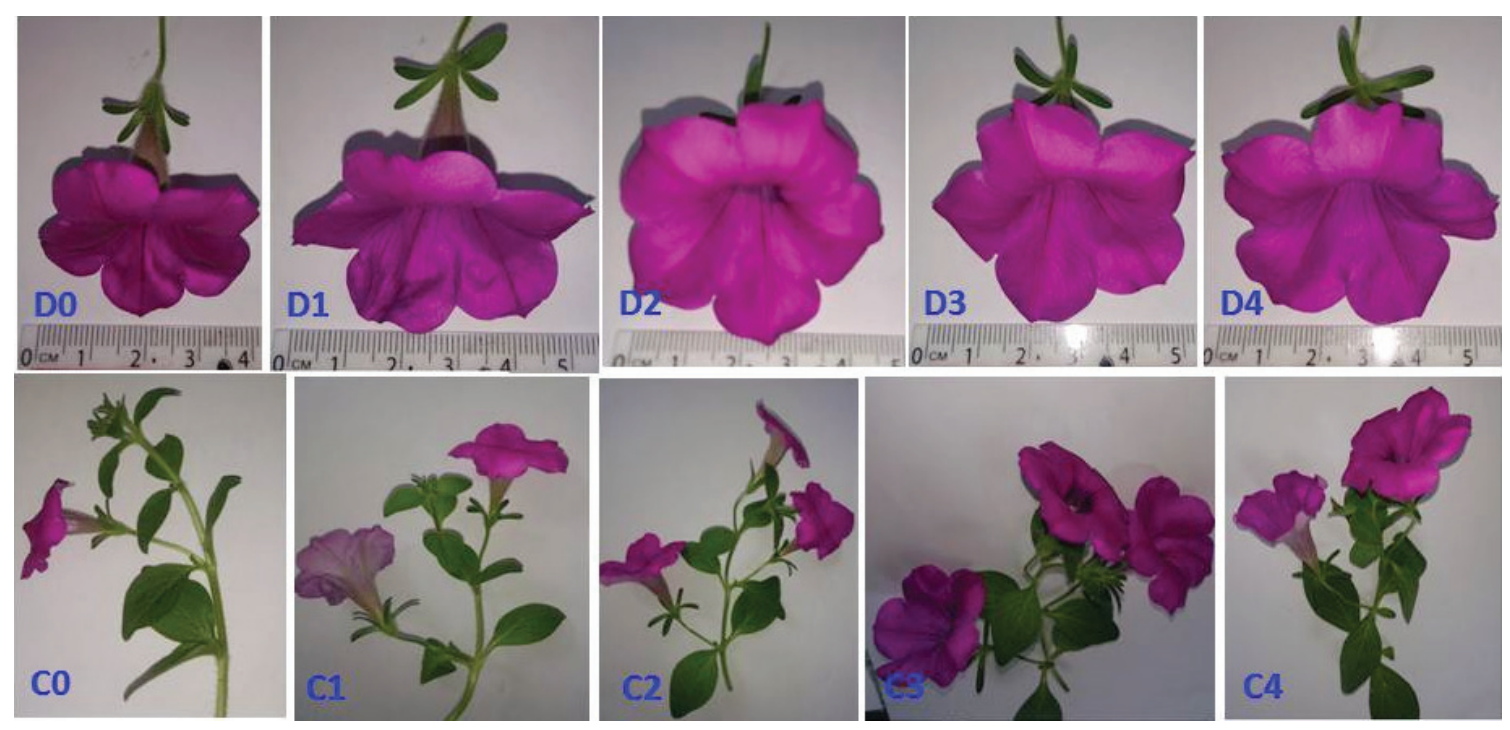

Figure 2- The effect of different growing media on flowers number (C) and flower diameter (D) of potted petunia plants. 0, Control; 1, Vermicompost; 2, Biochar; 3, Cocopeat and 4, Peatmoss

Table 2- Effects of different growing media on flowering behaviour and quality of potted Petunia grandiflora

\begin{tabular}{llllll}
\hline Treatment & $\begin{array}{l}\text { Number of Bud/ } \\
\text { plant }\end{array}$ & $\begin{array}{l}\text { Number of } \\
\text { flower/plant }\end{array}$ & $\begin{array}{l}\text { Flower diam } \\
(\mathrm{mm})\end{array}$ & $\begin{array}{l}\text { Wt of ind } \\
\text { flower }(\mathrm{g})\end{array}$ & $\begin{array}{l}\text { Petal thickness } \\
(\mathrm{mm})\end{array}$ \\
\hline Control & $3.20 \pm 0.60 \mathrm{~b}$ & $3.00 \pm 0.80 \mathrm{c}$ & $33.50 \pm 0.90 \mathrm{c}$ & $0.12 \pm 0.02 \mathrm{c}$ & $0.08 \pm 0.00 \mathrm{c}$ \\
Vermicompost & $18.40 \pm 2.00 \mathrm{a}$ & $21.70 \pm 2.00 \mathrm{~b}$ & $47.10 \pm 0.60 \mathrm{a}$ & $0.18 \pm 0.02 \mathrm{~b}$ & $0.09 \pm 0.00 \mathrm{c}$ \\
Biochar & $21.80 \pm 9.00 \mathrm{a}$ & $28.50 \pm 2.30 \mathrm{a}$ & $41.90 \pm 3.00 \mathrm{~b}$ & $0.21 \pm 0.02 \mathrm{~b}$ & $0.08 \pm 0.00 \mathrm{c}$ \\
Cocopeat & $18.00 \pm 5.00 \mathrm{a}$ & $32.40 \pm 2.00 \mathrm{a}$ & $46.80 \pm 2.00 \mathrm{a}$ & $0.22 \pm 0.01 \mathrm{~b}$ & $0.10 \pm 0.00 \mathrm{~b}$ \\
Peatmass & $20.10 \pm 1.50 \mathrm{a}$ & $29.80 \pm 1.20 \mathrm{a}$ & $52.50 \pm 3.40 \mathrm{a}$ & $0.29 \pm 0.03 \mathrm{a}$ & $0.12 \pm 0.00 \mathrm{a}$ \\
\hline
\end{tabular}

Data was present in means $( \pm \mathrm{SE})$. Different means in same column followed by same letter are not different according to LSD test at $\mathrm{P}=0.05$ probability 
effect on weight of individual flower. Based on Figure 2 and Table 2, the highest value was recorded in peatmoss at $0.29 \mathrm{~g}$ followed by cocopeat at $0.22 \mathrm{~g}$. The lowest value was observed in the control treatment at $0.12 \mathrm{~g}$. Based on Table 2, the highest petal thickness was recorded in peatmoss treatment at $0.12 \mathrm{~mm}$, followed by the cocopeat and vermicompost with a value of 0.10 and $0.09 \mathrm{~mm}$, respectively. Control and BioChar treatments produced the thinner petal with a petal thickness of $0.08 \mathrm{~mm}$.

\subsection{Chlorophyll content (SPAD) and Chlorophyll $a \& b$}

The results showed that chlorophyll content of potted petunia plant was similar among the growing media except for the control. Results showed that growing media used in this study enhanced relative chlorophyll content as compared to control (Table 3). Based on Table 3, the SPAD chlorophyll value was the highest in peatmoss treatment with a mean value of 24, followed by cocopeat and vermicompost treatments. For Chlorophyll $a$, peatmoss growing media produced the highest amount of leaf chlorophyll $a$, followed by cocopeat, vermicompost and biochar. While, the lowest amount of chlorophyll $a$ was recorded in control treatment (Table 3). Similar trend was also obtained for chorophyll $b$ content, which was 1.75 times higher in peatmost treatment as compared to the control (Table 3).

\subsection{Carotene and anthocyanin contents}

Based on Table 3, there were significant differences for both caratone and anthocyanin contents among the treatments. The highest carotenoid content was obtained with peatmoss treatment at 1.00 $\mu \mathrm{g} \mathrm{g}^{-1}$, followed by cocopeat with a value of 0.70 $\mu \mathrm{g} \mathrm{g}^{-1}$. The lowest reading was recorded in the control plant with carotenoid content of $0.30 \mu \mathrm{g}$ $\mathrm{g}^{-1}$. Anthocyanin content in petunia flowers petal was also significantly affected by growing medium under potted condition (Table 3 ). The results showed that petunia grown in peatmoss medium produced 2.3 times more anthocyanin content as compared to the control treatment. It was also seen that all the treatments produced darker petal colour compared to control (Figure 3).

\subsection{Flower longevity, ethylene production and correlation between petal thickness and flower longevity}

All the treatments increased the longevity of potted petunia flowers compared to control and the best growing media were peatmoss and vermicompost (Figure 3). The highest flower longevity (days) was recorded in peatmoss treatment at 15 days while the less flower longevity was recorded in the control treatment ( 9 days) (Figure 4a). Results showed that the rate of ethylene production of potted petunia flowers was significantly affected from growing media (Figure 4b). Petunia plants grown in top soil (control) produced the highest amount of ethylene than the peatmoss, biochar, cocopeat and vermicompost. The results showed that the petal thickness and anthocyanin content have had positive correlation with the flower longevity of petunia flower (Figures $5 \mathrm{a}$ and $\mathrm{b}$ ). Flower longevity was enhanced with the increase in petal thickness and anthocyanin content of petunia petal (Figures 5a and b).

Table 3- Effects of different growing media on accumulations of pigments in potted petunia flowers

\begin{tabular}{llllll}
\hline Treatment & $\begin{array}{l}\text { Chlo cont } \\
\text { (SPAD) }\end{array}$ & $\begin{array}{l}\text { Chlo } \\
a\end{array}$ & $\begin{array}{l}\text { Chlo } \\
\mathrm{b}\end{array}$ & $\begin{array}{l}\text { Carotene } \\
\text { cont }\left(\mu g \mathrm{~g}^{-1}\right)\end{array}$ & $\begin{array}{l}\text { Anthocyanin } \\
\text { content }\left(\mathrm{mgg}^{-1} \mathrm{FW}\right)\end{array}$ \\
\hline Control & $13.40 \pm 0.80 \mathrm{~b}$ & $6.50 \pm 0.80 \mathrm{c}$ & $2.00 \pm 0.10 \mathrm{~b}$ & $0.30 \pm 0.00 \mathrm{~d}$ & $0.10 \pm 0.02 \mathrm{c}$ \\
Vermicomposte & $22.40 \pm 0.40 \mathrm{a}$ & $7.80 \pm 0.80 \mathrm{~b}$ & $3.10 \pm 0.30 \mathrm{a}$ & $0.40 \pm 0.10 \mathrm{c}$ & $0.20 \pm 0.01 \mathrm{a}$ \\
Biochar & $18.60 \pm 0.40 \mathrm{a}$ & $7.70 \pm 0.90 \mathrm{~b}$ & $2.90 \pm 0.20 \mathrm{a}$ & $0.55 \pm 0.00 \mathrm{c}$ & $0.15 \pm 0.03 \mathrm{~b}$ \\
Cocopeat & $22.80 \pm 0.60 \mathrm{a}$ & $8.50 \pm 0.50 \mathrm{~b}$ & $3.20 \pm 0.40 \mathrm{a}$ & $0.70 \pm 0.20 \mathrm{~b}$ & $0.18 \pm 0.02 \mathrm{a}$ \\
Peatmoss & $24.30 \pm 0.50 \mathrm{a}$ & $9.50 \pm 0.70 \mathrm{a}$ & $3.50 \pm 0.40 \mathrm{a}$ & $1.00 \pm 0.10 \mathrm{a}$ & $0.23 \pm 0.02 \mathrm{a}$ \\
\hline
\end{tabular}

Data was present in means ( \pm S E). Different means in same column followed by same letter are not different according to LSD test at $\mathrm{P}=0.05$ of probability 


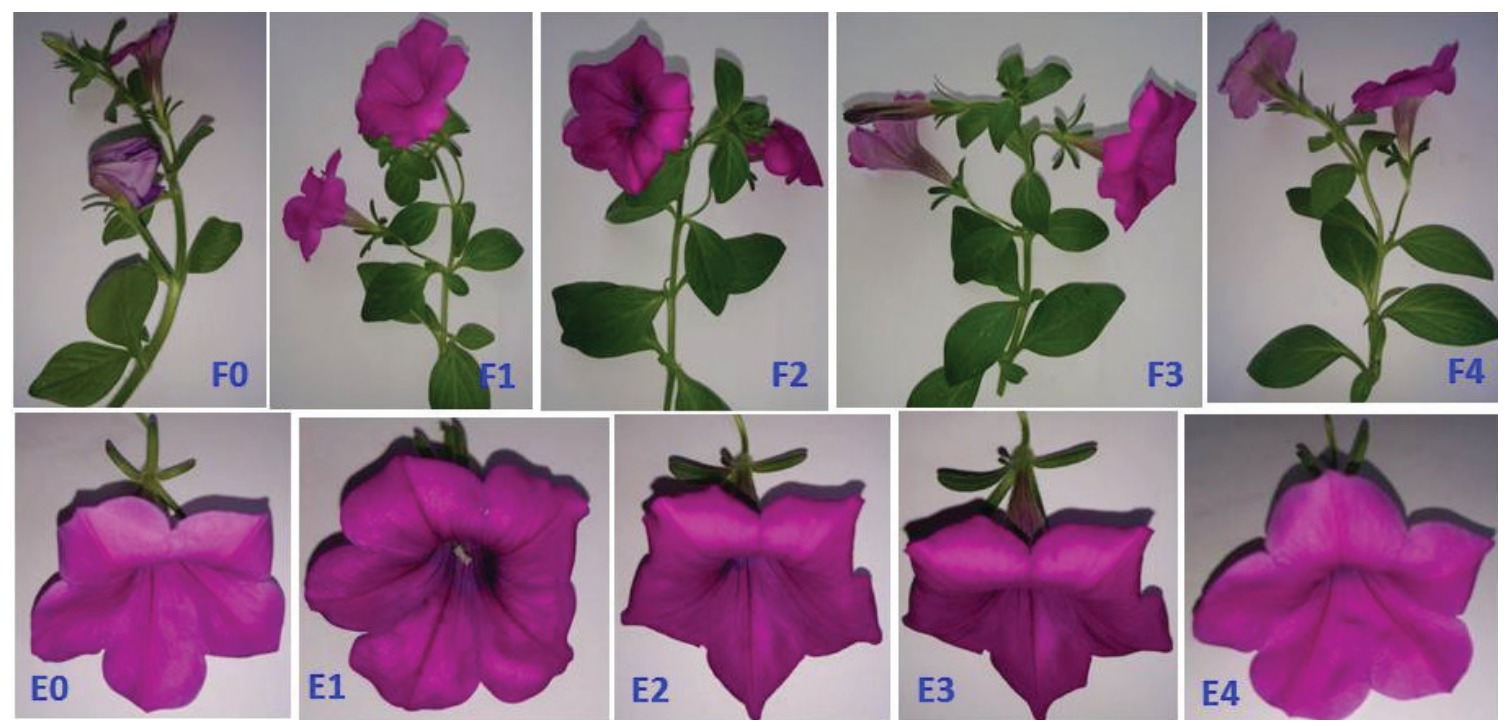

Figure 3- The effect of different growing media on petal colour (e) and flower logevity (f) of potted petunia plants. 0, Control; 1, Vermicompost; 2, Biochar; 3, Cocopeat and 4, Peatmoss
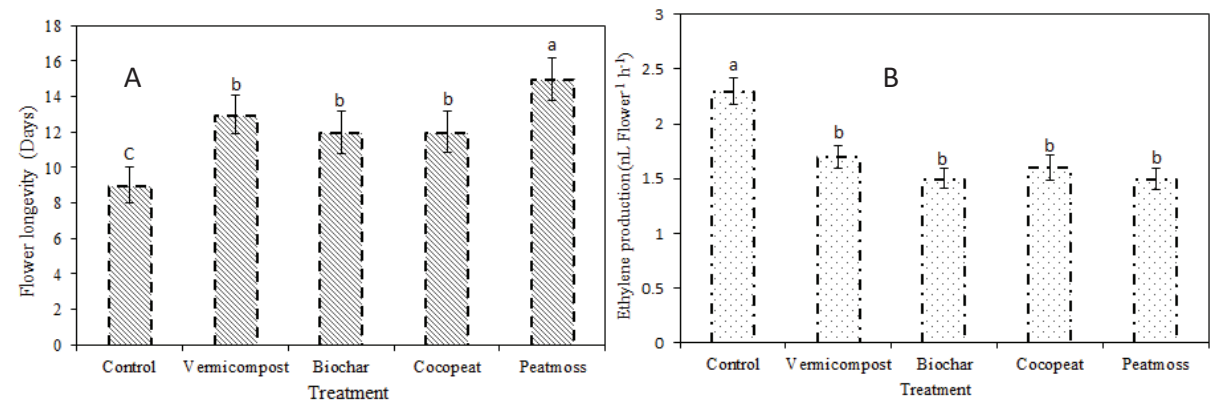

Figure 4- Effects of different growing media on flower longevity (a) and ethylene production rate (b) of potted petunia flowers
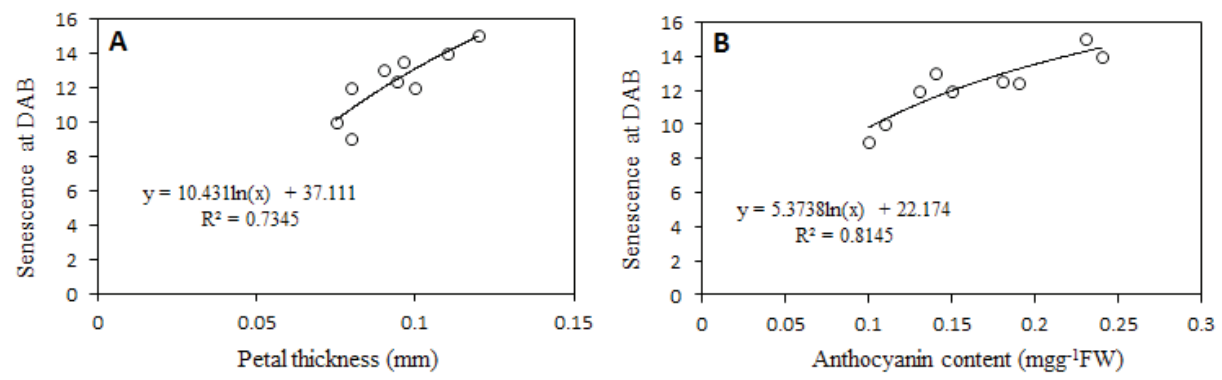

Figure 5- Correlation between petal thickness (a) and anthocyanin (b) with flower longevity of potted petunia plants. DAB, Days After Bloom 


\section{Discussion}

Plant productivity is largely dependent on leaf area, which is an important determinant of light interception, net photosynthetic rate, transpiration and other metabolic acitivities. In the present study, growing medias; peatmoss and cocopeat significantly increased the leaf area of potted petunia plants. Mehmood et al (2013) also stated that peatmoss-containing growing substrate greatly affects the size of leaves of Antirrhinum majus L. (cv. Floral Shower). This might be due to the high availability of nutrients in growing substrate during the vegetative and reproductive growth periods. Our results also showed that growing media produced significant effect on number and length of lateral branch of potted petunia plants. Cocopeat increased the number of lateral branches as compared to the other treatments. The results from current study are in accordance with the findings of Riaz et al (2008), who stated that the coconut compost increases the number of lateral branches. In our study, the vegetative growth; length of lateral branches was the highest in control treatment. The top soil $\mathrm{pH}$ was around 5.5 to 6.5 and it has higher percentage of clay and humus. The higher amount of organic matter and nitrogen present in the clay loam top soil might have stimulating impact on vegetative growth of petunia plant. Moreover, moisture holding capacity of the top soil is also very high thus it may stimulate more vegetative growth rather than reproductive growth.

Stomata occupy a central position in the pathway for the transport of water vapour for $\mathrm{CO}_{2}$ and $\mathrm{O}_{2}$ (Jones 1998). Different growing media produced a significant effect on stomatal aperture of potted petunia plants. Peatmoss and cocopeat increased the stomatal aperture of petunia plants. Peatmoss is considered as an optimal organic amendment to improve the physical properties of soil's $\mathrm{pH}$, moderate temperature, fine texture and good water retention ability. These improved physical conditions of growing media may increase the production of cytokinins, a hormone that is known to favor the opening of stomata (Stoynova et al 1996).
Results from this study indicated that growing media increases net photosynthetic rate of potted petunia plant. Among the growing media tested, peatmoss and cocopeat produced significant positive effect on photosynthesis of petunia plant. Similar results was reported by Nazari et al (2011), who stated that cocopeat singinificantly increased net photosynthetic rate, efficiency of mesophyll cells, fresh weight of flowering stem, and length of floret of potted hyacinth plant (Hyacinthus orientalis L.). It has been stated earlier that peatmoss and cocopeat stimulate the growth regulators activities and these growth regulators has a stimulatory effect on photosynthesis. Khandaker et al (2013) reported that application of Triacontanol to the potted Bougainvillea plant (Bougainvillea glabra) had increased the net photosynthetic rate and enhanced accumulation of photosynthates, thus enhance the flowering of potted plants.

In this current study, cocopeat and peatmoss significantly increased the number of flower bud and flower diameter in potted petunia plants. Enhanced floral quality by cocopeat and peat moss may be attributed to the stimulating effect of them on the activity of growth regulators which play a significant role in flower and fruit developments (Moneruzzaman et al 2013). Similar to our findings in petunia plants. Talukdar \& Barooah (1987) reported that cocopeat resulted with 'superior flowering' in Dendrobium densiflorum. Plants with the largest flowers are normally regarded as high quality and preferred by consumers for most purposes including bedded plants, cut flowers or potted plants. In this current research, potted petunia plants had better performance with the acidic growing media of peatmoss in which $\mathrm{pH}$ is around 4 because it is as acid loving ornamental plant (Argo \& Fisher 2008). Our results are in agreement with the findings of Hasan et al (2014), who reported that peatmoss and sheep manure increased the flowers number, floral diameter and petals number per flower of marigold (Calendula officinalis L.).

Peatmoss and cocopeat media produced positive effect on weight of individual flower. This might be due to the slightly acidic growing media with 
$\mathrm{pH}$ of around 4.0. The increment in the flower weight of petunia treated with peatmoss may be due to the peatmoss growing medium enhancing the biosynthesis of the plant growth hormones and protein, which subsequently affects the cell division and cell expansion in the reproductive organ of the petunia plant. May be this growing medium suppresses the vegetative growth and induces the reproductive growth of petunia. Petal thickness was increased significantly with peatmoss and cocopeat treatments. These results were in line with Hasan et al (2014), who reported that peatmoss significantly increased the number and size of petal of marigold. Applying peatmoss and cocopeat significantly increased the number of flowers of potted petunia plants and this may be due to the impact of nutrients in these organic extracts.

In this study, we measured the greenness of leaf by using the SPAD meter and determined the Chlorophyll $a$ and $b$ contents of potted petunia plant. All of the growing media significantly increased the chlorophyll content of leaves of petunia as compared to control. Our results showed an aggrement with the results of Hasan et al (2014), who reported that peatmoss and sheep manure increased the leaf chlorophyll content of marigold plant. Carotenoids are important in plant system due to light harvesting complex and in the photoprotection of the photosystem. Peatmoss significantly increased the carotenoids content of petunia flower. Flower quality was enhanced with the use of peatmoss as a growing media. These results were supported by the findings of Sardoei \& Rahbarian (2014), who reported that peatmoss growing media increased photosynthetic pigments and carotenoids content in ornamental plants.

The red or pink colour that appears on the flowers or fruits arises from the accumulation of anthocyanins (Khandaker et al 2012). The results from this study showed that a growing medium produced a significant effect on anthocyanin content of petunia petal, and the highest anthocyanin content was recorded in acidic growing media of peatmoss and cocopeat-treated petunia plant. Our results were also supported by the findings of Schmitzer
\& Stampar (2010), who reported that the rose plants planted in growth medium with a lower $\mathrm{pH}$ would had more anthocyanins in rose petal. They also stated that acidic growing media may increase the availability of $\mathrm{Zn}$ in root zone and this in turn increase the accumulation of plant anthocyanin content. It has also been also reported that the mircronutrients iron, manganese, and zinc become more available as $\mathrm{pH}$ decreases in the plant growing medium (Hannan 2016).

The results showed that peatmoss increased the longevity of potted petunia flower around 6 days as compared to control plant. Asghari (2014) also reported that growing medium significantly affects the flower character as well as longevity of carnation (Dianthus caryophyllus L.) flowers. This might be due to increases of available moisture supply, nutrient content and cation exchange capacity (CEC) of potted plant. Moreover, it has been reported earlier that peatmoss is an acidic growing media with $\mathrm{pH}$ of around 4 , and this low $\mathrm{pH}$ value may also reduce the $\mathrm{pH}$ of plant cell $(\mathrm{pH}$ 6 ) and decrease the rate of ethylene production after flowering. Flower longevity and abscission of bract is also correlated with ethylene production (Moneruzzaman et al 2010). The findings of this current study indicated that petunia plants grown in soilless media decreased the ethylene production. This might be due to increased availability of water and nutrients, and production of gibberellin and cytokinin hormones in plants grown in the peatmoss and other growing media, which would extend the reproductive growth of petunia plants. This improved growth might have retarded the ethylene production and increased flower longevity. Aharoni (1989) reported that exogenous treatments of $\mathrm{GA}_{3}$ and kinetin retards the senescence, as well as reduced the biosynthesis of ethylene in plant parts.

In our study, we have found positive correlation among the petal thickness and longevity of petunia flower on the plant. Similary, Breadmore \& Kirk (1998) reported that the amount of petal demages strongly correlated with petal thickness of herbaceous plant, which may be due to higher carbohydrate reserve and enables to maintain the 
dry matter in the petals which help in extending the keeping quality. Khandaker et al (2011) also reported that girdling increase the carbohydrates availability in the above parts of girdle branch and reduced the floral bud drop. It was observed that anthocyanin concentration in petal affect the vase life of petunia flower and both parameters were positively corrected. Flowers from petunia plants treated with peatmoss and cocopeat have high anthocyanin content as well as flower longevity. Our results were suported by the findings of Emami et al (2011), who reported that anthocyanin content had the highest direct effect on flower longevity of lily and flower longevity has a positive correlation with initial fresh weight of flower, and anthocyanin and carotenoid contents.

\section{Conclusions}

Based on results, it can be concluded that the peatmoss and cocopeat enhanced the growth, development and improved the floral quality of Petunia grandiflora. Cocopeat showed better performances in number of flower, number of lateral branch and length of lateral branch. On the other hand, peatmoss showed a better performance in diameter and weight of flower, petal thickness, chlorophyll content, stomatal conductance, carotene content and flower longevity. In addition, peatmoss and cocopeat siginificantly increased the net photosynthetic rate of potted petunia plants, chlorophyll $a$ and $b$, and carotenoids and anthocyanin contents in flowers petal. Moreover, a decreased ethylene production but an increased flower longevity were of advantages of peatmoss and cocopeat. Hence, for potted Petunia grandiflora, the use of peatmoss and cocopeat as a growing media is strongly recommended to improve production.

\section{Acknowledgements}

We greatly thank to Research Management, Innovation \& Commercialization Centre (RMIC), Universiti Sultan Zainal Abidin, Terengganu, Malaysia for the publication support.

\section{References}

Aharoni N (1989). Interrelationship between ethylene and growth regulators in the senescence of lettuce leaf discs. Journal of Plant Growth Regulation 8: 309-317

Argo W F \& Fisher P R (2008). Understanding MediapH Management. Greenhouse Grower November pp. 61-64

Arnon D I (1949). Copper enzyme in isolated chloroplast polyphenoloxidase in Beta vulgaris. Plant Physiology 24(1): 1-15

Asghari R (2014). Effects of growth medium and planting density on growth and flowering characteristics carnation. International Journal of Pure and Applied Sciences and Technology 23(2): 28-34

Breadmore K N \& Kirk W D J (1998). Factors affecting floral herbivory in a limestone grassland. Acta Oecologica 19(6): 501-506

Emami H, Saeidnia M, Oflati J A \& Hasani M (2011). Study on lily longevity treated with growth regulators $\left(\mathrm{GA}_{3}\right.$ and BA) by Path analysis. American-Eurasain Journal Agriculture \& Environmental Science 10(5): 814-820

Hannan J (2016). Soil pH in The Home Garden. Iowa State University Ames, Iowa 50011. Retrieved in May, 10, 2016 from https://hortnews.extension. iastate.edu/2016/02-12/soilpH/

Hasan A E, Bhiah K M \& Al-Zurfy M T H (2014). The impact of peat moss and sheep manure compost extracts on marigold (Calendula officinalis L.) growth and flowering. Journal of Organic Systems 9(2): 56-62

Jones H G (1998). Stomatal control of photosynthesis and transpiration. Journal of Experimental Botany 49(1): 387-398

Khandaker M M, Hossain A B M S, Normaniza O, Saifudin M, Sani W \& Amru N B (2010). Effects of removal of young leaves and cytokinin on inflorescence development and bract enlargement in Bougainvilea glabra var. "Elizabeth Angus". Australian Journal of Crop Science 4(7): 467-473

Khandaker M M, Hossain A B M S, Osman N \& Boyce A N (2011). Application of girdling for improved fruit retention, yield and fruit quality in Syzygium samaragense under field conditions. International Journal of Agriculture and Biology 13(1): 18-24

Khandaker M M, Boyce A N \& Normaniza O (2012). The influence of hydrogen peroxide on the growth, 
development and quality of wax apple (Syzygium samarangense, [Blume] Merrill \& L.M. Perry var.jambu madu) fruits. Plant Physiology and Biochemistry 53(4): 101-110

Khandaker M M, Faruq G, Rahman M M, Sofian A M \& Boyce A N (2013). The influence of 1-Triacontanol on the growth, flowering, and quality of potted Bougainvillea plants (Bougainvillea glabra var. "Elizabeth Angus") under Natural Conditions. Scientific World Journal 2013: 1-12

Khobragade R I, Damke M M \& Jadhao B J (1997). Effect of planting time and spacing on growth, flowering and bulb production of tuberose (cv. Single). Acta Horticulturae 21: 44-47

Mehmood T, Ahmad W, Ahmad K S, Shehzad M A \& Sarwar M A (2013). Comparative effect of different potting media on vegetative and reproductive growth of floral shower (Antirrhinum majus L.). Universal Journal Plant Science 1(3): 104-111

Moneruzzaman K M, Hossain A B M S, Saifuddin M, Imdadul H, Normaniza O \& Amru N B (2010). Effects of sucrose and kinetin on the quality and vase life of Bougainvillea glabra var. Elizabeth angus bracts at different temperature. Australian Journal of Crop Science 4(7): 474-479

Moneruzzaman K M, Boyce A N, Normaniza O, Faruq G, Motior Rahman M \& Sofian-Azirun M (2013). Fruit development, pigmentation and biochemical properties of wax apple as affected by localized application of $\mathrm{GA}_{3}$. Brazilian Achieves of Biology and Technology 56(1): 11-20

Nazari F, Homayoun F, Morteza K K \& Hassan S (2011). Effects of coir as a component of potting media on growth, flowering and physiological characteristics of hyacinth. International Journal of Agricultural and Food Science 1(2): 34-38
Nishijima T, Miyaki H, Sasaki K \& Okazawa T (2006). Cultivar and anatomical analysis of corolla enlargement of petunia (Petunia hybrida Vilm.) by cytokinin application. Scientia Horticulturae 111(1): 49-55

Riaz M, Ahmad M, Sarwar M \& Raza S H (2008). Nutritional evaluation of sugarcane tops in conventional feeding management system during fodder scarcity season of Pakistan. International Journal of Agriculture and Biology 10(6): 665-668

Rodriguez-Saona L E, Giusti M M \& Wrolstad R E (1999). Wrolstad, R. E. Color and pigment stability of red radish and red-fleshed potato anthocyanins in juice model systems, Journal of Food Science 64(3): 451-456

Sardoei A S \& Rahbarian P (2014). Effect of different media on chlorophyll and carotenoids of ornamental plants under system mist. European Journal of Experimental Biology 4(2): 366-369

Schmitzer V \& Stampar F (2010). Substrate pH level effects on anthocyanins and selected phenolics in rosa $\times$ hybrida L. 'KORcrisett. Acta Agriculturae Slovenica 59(1): 5-11

Stoynova E Z, Iliev L K \& Georgiev G T (1996). Structural and functional alterations in radish plants induced by the phenylurea cytokinin 4-PU-30, Biology Plantatum 38(6): 237-244

Talukdar M \& Barooah S (1987). Effect of pot mixture on flowering in Dendrobium densiflorum. Acta Horticulturae 205(21): 145-148

Zhanga W, Li X, Chenb F \& Lua J (2012). Accumulation and distribution characteristics for nitrogen, phosphorus and potassium in different cultivars of Petunia hybrida Vlim. Scientia Horticulturae 141(6): 83-90 